\title{
Digital maturity of territories during digital transformation
}

\author{
Yuner Kapkaev ${ }^{1, *}$ and Pavel Kadyrov ${ }^{1}$ \\ ${ }^{1}$ Chelyabinsk State University, 129, Bratiev Kashirinykh str., Chelyabinsk, Russia
}

\begin{abstract}
The formation of a full-fledged digital national economy integrated into a single world order is today's trend. Under a single technological human habitat, it is necessary to understand territories as separate systemic mechanisms of the state, lined up in a logical sequence region-city-municipality city-municipality of each element's region position to the previous and subsequent ones. That is consideration of the socio-economic development of the system from the standpoint of the agglomeration effect. Based on the above, the article considered various approaches to identifying a territory from the point of view of digital maturity in the global digital transformation process. The existing methods for assessing the digital maturity of Russian regions are considered, groups of metrics for such an assessment are given, and a critical assessment of existing methods is given to develop new ones or improve old ones. The rationale for this is the ability to track digital transformation dynamics through the digital maturity of territories.
\end{abstract}

\section{Introduction}

The exponential growth of data storage capacities, processing, transmission speeds, and expanding access to the worldwide network

is the primary digitalization condition. Through the constantly accelerating scientific, technical progress process, a full-fledged technological environment of "habitation" has been formed, which has analytical and predictive functions to form a friendly environment.

We can scale such a technological "habitat" in different ways, from a global technological "habitat" to a technological "habitat", a subject of the Russian Federation - a city of a subject of the Russian Federation - a municipality of a city of a subject of the Russian Federation. Nevertheless, here it is necessary to mention an important point, namely in Maltsev.A. and Maltsev V. [1], digital transformation is a controversial process that can both contribute to the achievement of sustainable development results unwittingly hinder their implementation. For digital transformation to contribute to sustainable development results, a targeted and coordinated intergovernmental policy with national and business communities' participation is essential.

"Smart region" is a territory of innovative development that uses ICT and other means to improve the standard of living, the efficiency of human activity and the competitiveness of the economy while ensuring that the needs of present and future generations are met in

*Corresponding author: zam@csu.ru 
economic, social and environmental aspects. This definition is confirmed by our colleague N. Kasavina and supplements it from the point of view that new information technologies deserve a critical assessment of the social and humanitarian consequences of their development and require interdisciplinary thinking in terms of new philosophical and humanitarian alternatives [2].

There are different approaches to understanding the "smart region":

- From a technological point of view, a smart region is a tool for improving the quality of vital indicators of people living in a specific territory;

- From an information point of view, a smart region is the presence of a system for generating and managing information flows in order to increase intelligence, which in turn is necessary for objective goal-setting, resource planning, and building a strategy for achieving goals in a specific territory;

- From the point of view of sustainable development, a smart region is a tool aimed at the socio-ecological economic development of the territory in the medium and long-term planning horizon. The core of sustainable development here should be understood as a set of innovations to improve the environment and the volume of investments to introduce a set of innovations. This approach can be supplemented with the ideas of I. Naumov, J. Dubrovskaya, E. Kozonogova that the digital transformation of industrial enterprises is becoming a key factor of territorial competitiveness, determining the prospects for regional development and the possibility of increasing the growth rates of the national economy [3];

- From the point of view of humanism, a smart city is a tool to solve social problems that have arisen and are transformed over time under the influence of exogenous and endogenous factors.

As an example of implementing the above approaches in creating a smart territory, we can cite world examples of the formation of a smart city mission as an integral part of a smart territory (fig. 1).

According to V. Tsirenshchikov, at different stages of the evolution of territories, the formation of systemic components of smart infrastructure underwent conceptual changes [4].

At the first evolutionary stage, the formation of the physical infrastructure, its reequipment on a new technological basis, and local IT solutions' introduction took place largely independently of each other.

The second evolutionary stage can be characterized as a partial and limited integration of the physical infrastructure and the locally existing IT solution. An important component here is the emergence of a request to create a centralized system, with the help of which users will have a single point of access to various local services. 


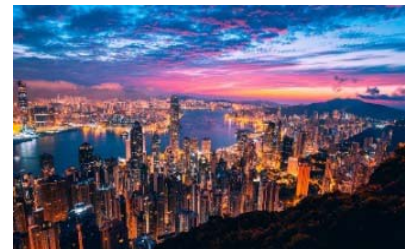

Hong Kong

"Leveraging innovation and technology to create Smart Hong Kong world-renowned,

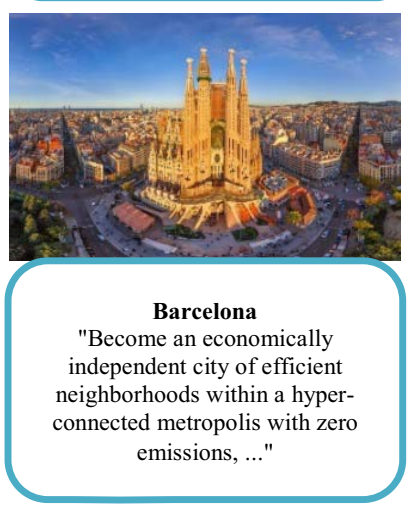

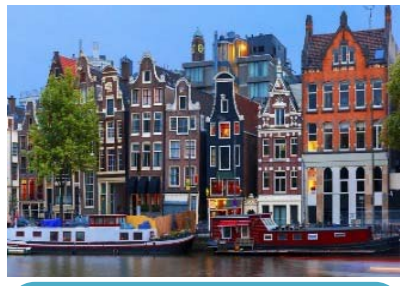

Amsterdam

"We influence urban innovation, ..."

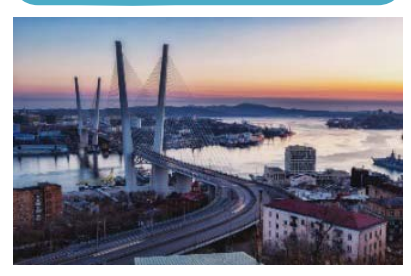

Vladivostok

"A modern city by the sea, which will not torment nature and the wallets of residents ..."
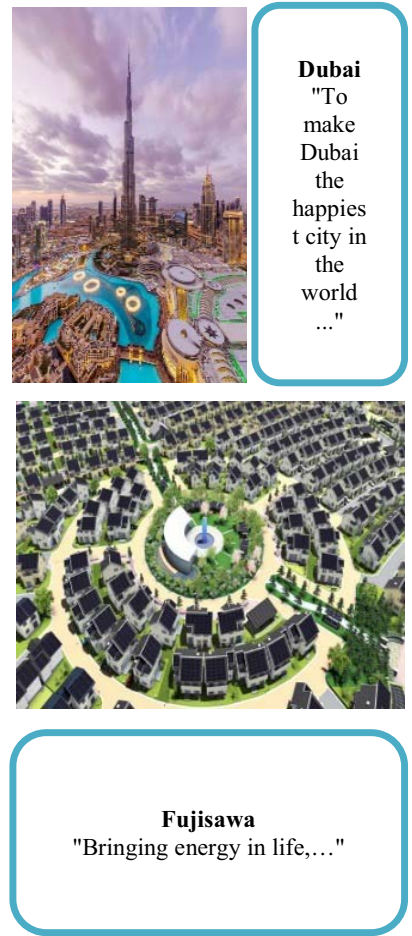

Fig. 1. World practice of forming a smart city mission (Source: compiled by the authors).

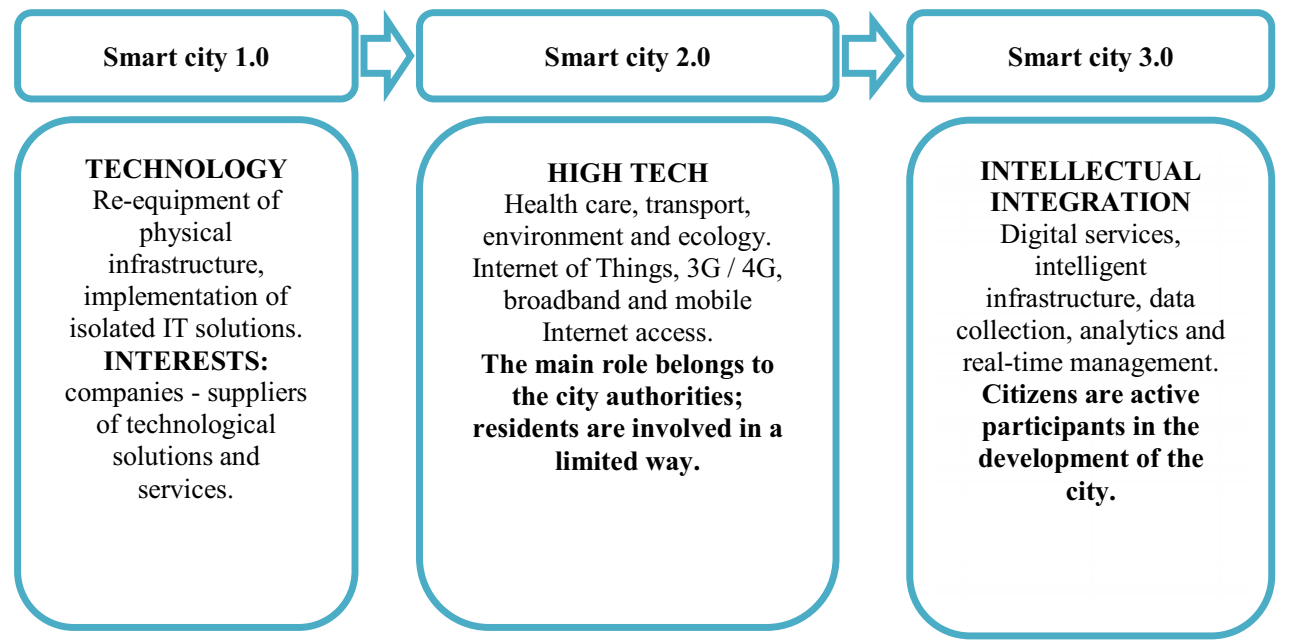

Fig. 2. Evolution of the formation of a smart territory on the example of the concept of "Smart city" (Source: compiled by the authors).

The main result of the third evolutionary stage is the emergence of digital services (eventually combined into one) to provide services, serving its intelligent infrastructure, the functionality of which is based on the process of collecting a large amount of data, analyzing and making decisions in real-time. At this stage, the elements of a shared consumption system are being formed, in this regard, it is worth mentioning the research D. Pletnev, E. Nikolaeva and E. Silova on the development of the sharing economy in Russia, where the typology of the sharing economy is presented. The fastest-growing markets are 
described: C2C sales, social savings (joint purchases), rental of goods, P2P services in direct recruitment (freelancing), crowdfunding and car-sharing [5].

The result that the state is striving for in the process of forming a smart territory is understandable; in particular, it is the creation of a hybrid mechanism based on new technologies and traditional approaches - the digital system is responsible for the process of dynamically attracting relevant resources, and the traditional one for the accumulation and redistribution of risks.

The key risks here may be:

- the presence of basic dead-end technologies, as well as outdated standards;

- problem with data security, cost-sharing and the digital divide;

- resistance of labor resources (officials), whose functions have exhausted themselves after digitizing their processes.

Development of regions in Russia is a request, but not one-way communication "You give us". It is constructive two-way communication to give and substantiate the interest of the Federal authorities and the options for covering this interest ". The formula development $=$ request is justified by the fact that the economic region, as a territory with a high degree of interconnectedness and interdependence of economic entities, based on the unity of the labor market and raw materials, a single economic infrastructure, as well as close intra- and inter-industry cooperation.

From the standpoint of the digital development of the territory, several problems have accumulated over the years that impede the formation of territories' digital transformation.

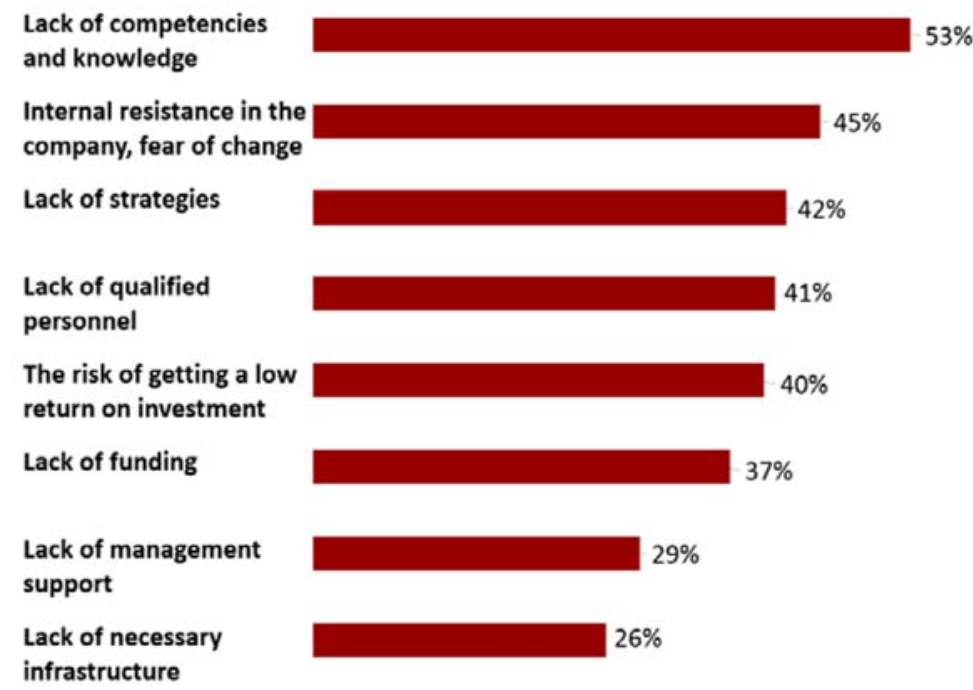

Fig. 3. Problems of territories hindering digital transformation of territories (Source: KMDA. Digital transformation in Russia - 2020).

The solution of the accumulated socio-economic problems of Russian regions can be carried out based on the development and use of regional factors of production and the use of the unique advantages and diversification of the territory's economy through the use of advanced technologies. It helps develop digital services and combine them into a single integrated system that can provide a qualitative leap in regions' social-economic development. According to K. Chetty, L. Qigui, N. Gcora, J. Josie, L. Wenwei and Ch. Fang, in order to promote digital transformation, it is necessary to pay equal attention to digital skills development and infrastructure development. Their study evaluates mechanisms to ensure adequate governance of digital learning programs using a 
standardized data collection system to measure an internationally recognized digital literacy index [6]. Summing up the description of the existing points of view on digital transformation, it is obvious that the implementation of digital transformation requires a holistic methodological and methodological basis, which implies multiple indicators and sub-indicators, their classification and grouping into groups and subgroups.

\section{Materials and Methods}

Spatial processes lead to a change in indicators characterizing the socio-economic situation of territories (regions) considered in regional economic studies: for example, average per capita income, labor productivity, capital productivity, capital-labor ratio, economic openness coefficients, regional product structure, production localization coefficients and territorial specialization, employment structure, unemployment rate, gender, age and social characteristics of the population, population density, human development index. Today, overcoming the COVID-19 crisis can undoubtedly be called the critical spatial process of changing the world order. According to several authors T. Lanshina, V. Barinova, A. Kondratyev, M. Romantsov, the key areas of sustainable development that can create new economic development opportunities soon are renewable energy sources and clean transport, cyclical economy, digitalization, and environmental protection. Wednesday [8].

The following approaches, methods, and competencies [9] to assess the digital development of Russian territories were analyzed:

1. Index "Digital Russia" (Skolkovo)

Reflects the level of use in the subject of the Russian Federation of the potential of digital technologies:

- in economic activities,

- business processes;

- products;

- services and approaches to decision making.

The main goal is to modernize the socio-economic infrastructure of the region.

The sub-indices are:

- normative regulation and administrative indicators of digitalization;

- specialized personnel and training programs;

- availability and formation of research competencies and technological groundwork, including the level of research and development work;

- information infrastructure;

- Information Security;

- economic indicators of digitalization;

- social effect from the introduction of digitalization

2. IQ index of cities (Ministry of Construction of the Russian Federation)

Reflects the effectiveness of the urban economy's digital transformation segments, which have the greatest and least impact on the socio-economic development of the urban economy.

It consists of 10 directions, which add up indicators and sub-indicators:

- Urban governance (5 indicators);

- Smart housing and communal services (5 indicators);

- Innovation for the urban environment (6 indicators);

- Smart city transport (11 indicators);

- Intelligent public safety systems

(5 indicators);

- Intelligent systems of environmental safety

(4 indicators); 
- Tourism and service (4 indicators);

- Intelligent systems of social services (4 indicators);

- Economic condition and investment climate

(2 indicators);

- Infrastructure of communication networks (1 indicator).

3. Indicators of smart cities (NIITS Technologies and Communications)

Reflects the level of development of smart city technologies in large Russian cities. Indicators provide a clear indication of which direction a city is going to take when developing a smart city strategy. Indicators of a SWOT analysis of the implementation of digital technologies in the functioning of the urban economy.

It consists of 10 directions, which are composed of indicators and sub-indicators:

- Smart economy;

- Smart management;

- Smart residents;

- Smart technologies;

- Smart environment;

- Smart infrastructure;

- Smart finance.

Based on the assessment results, the assessment objects are divided into groups of beginners, developing, effectively developing, leaders.

As the basic techniques, a particular starting point of the study, the three abovedescribed techniques were chosen. A significant drawback of existing approaches is the absence in the calculations of the interconnection level and mutual influence of indicators and sub-indicators among themselves. It would also be interesting to see the dynamics of a particular territory's digitalization process, see it in the development-implementation-launch ratio, and the intermediate-final effect from use. That is, proceeding from the logic of tracking the intermediate and final result in dynamics, we understand such a concept as the digital maturity of the territory - an integral indicator showing the process of digital transformation of territories in dynamics.

\section{Results}

It is necessary first to determine the purpose of assessing the digital maturity of territories. The process of assessing the digital maturity of territories is a multi-level study of the territories' economy's critical sectors ( 5 sectors), which allows you to assess the potential of its growth, identify development zones, and develop an individual strategy for digital transformation. One of the key points in this definition is the individual digital transformation strategy since The Russian Federation is the world's largest territorial state and has excellent territorial development heterogeneity. We mean a gap in the level and quality of life of central and peripheral territories, determined by multiple economic indicators - GDP, the ratio of GDP to GRP of a particular territory, investments in fixed assets, labor productivity, industrial production index and many others). 


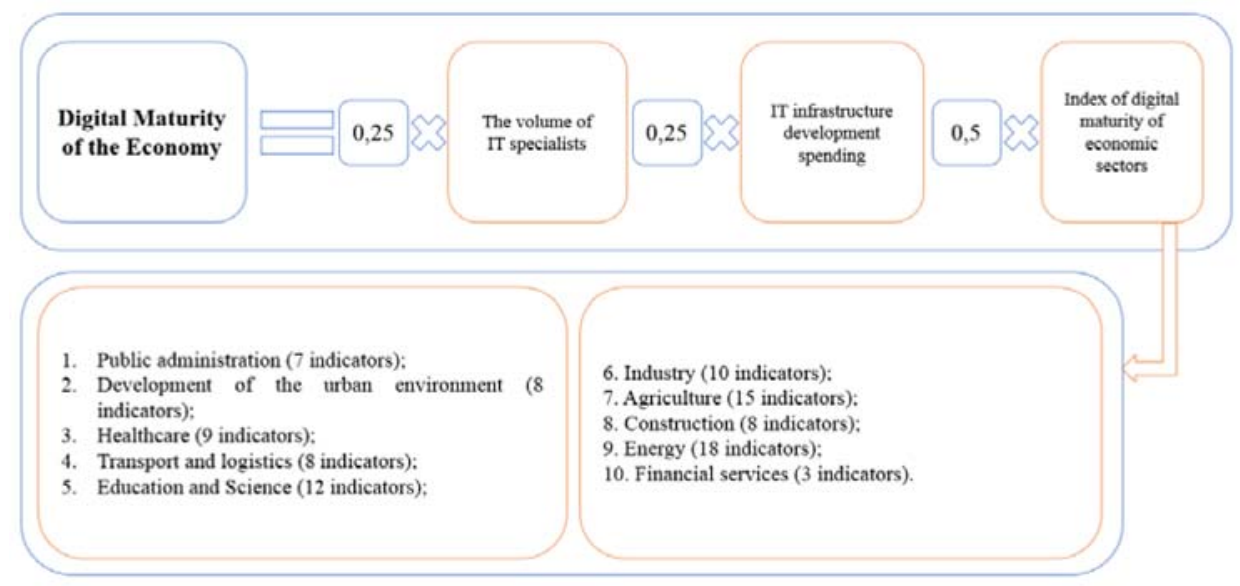

Fig. 4. Algorithm for assessing the digital maturity of the economy (Federal level) (Source: Ministry of Digital Development, Communications and Mass Media of the Russian Federation. Analytical materials, 2021).

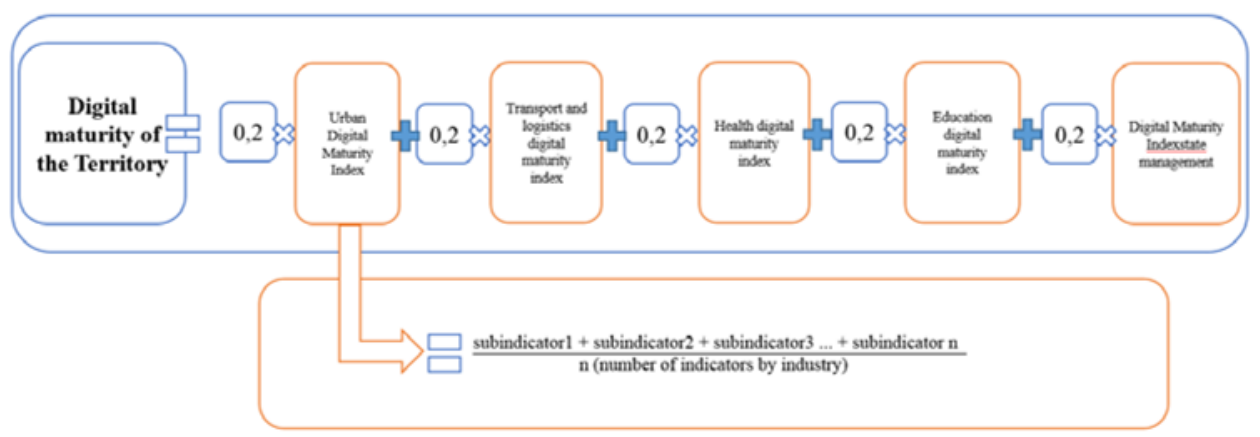

Fig. 5. Algorithm for assessing the digital maturity of the territory (Source: Ministry of Digital Development, Communications and Mass Media of the Russian Federation. Analytical materials, 2021).

Table 1. List of sub-indicators for calculating key indices of digital maturity of the territory.

\begin{tabular}{|c|c|}
\hline Index & Subindex \\
\hline $\begin{array}{c}\text { Urban } \\
\text { Development } \\
\text { Index }\end{array}$ & $\begin{array}{l}\text { - Share of general meetings of owners of premises in apartment buildings, } \\
\text { held by electronic voting, of the total number of general meetings of owners } \\
\text { - Share of services for the management of an apartment building and the } \\
\text { maintenance of common property paid for online } \\
\text { - Share of utilities paid online } \\
\text { - The share of managing organizations that disclose information in full in the } \\
\text { GIS Housing and Communal Services } \\
\text { - The share of resource-supplying organizations that disclose information in } \\
\text { full in the GIS Housing and Communal Services } \\
\text { - Share of UDDS of municipal districts and urban districts connected to a } \\
\text { unified system for monitoring incidents and accidents at housing and } \\
\text { communal services facilities } \\
\text { - Share of dilapidated housing stock listed in the digital emergency housing } \\
\text { register } \\
\text { - The proportion of city dwellers over the age of } 14 \text { who have taken part } \\
\text { using digital technologies in decision-making on urban development issues }\end{array}$ \\
\hline
\end{tabular}




\begin{tabular}{|c|c|}
\hline $\begin{array}{c}\text { Transport and } \\
\text { logistics } \\
\text { index }\end{array}$ & $\begin{array}{l}\text { - Share of electronic cargo transportation by air } \\
\text { - The proportion of unmanned cargo aircraft } \\
\text { - The share of freight shipments by rail, processed electronically using the } \\
\text { services of Russian Railways } \\
\text { - The share of passenger transportation by rail, registered in electronic form } \\
\text { using the services of JSC "Russian Railways" } \\
\text { - Share of electronic cargo transportation by sea and inland waterways } \\
\text { - Share of cargo transportation by highly or fully automated vehicles driven } \\
\text { in unmanned mode } \\
\text {-The share of newly commissioned and reconstructed sections of the } \\
\text { backbone road network equipped with infrastructure that ensures interaction } \\
\text { with highly or fully automated vehicles driven in unmanned mode }\end{array}$ \\
\hline $\begin{array}{l}\text { Healthcare } \\
\text { Index }\end{array}$ & $\begin{array}{l}\text {-Percentage of appointments made by citizens remotely, including at EPGU } \\
\text { - The share of citizens who have formed integrated electronic medical } \\
\text { records, which are also available at EPGU } \\
\text { - The share of citizens who are under dispensary observation, for whom } \\
\text { remote monitoring of health status is provided, including at the EPGU } \\
\text { - Share of medical organizations processing and storing digital medical } \\
\text { images in the central archive of medical images } \\
\text { - The share of medical consultations conducted by the constituent entities of } \\
\text { the Russian Federation with the National Medical Research Center of the } \\
\text { Ministry of Health of Russia using videoconferencing } \\
\text {-Percentage of consultations conducted by a doctor with a patient, including } \\
\text { at EPGU, using video conferencing } \\
\text { - The share of citizens who have access to medical appointments } \\
\text { (prescriptions) in the form of an electronic document, including at the EPGU } \\
\text { The share of medicines and drugs purchased for budget funds, for which } \\
\text { centralized accounting of their distribution is provided } \\
\text { - The share of stations (departments) of emergency medical care connected to } \\
\text { the use of a unified electronic dispatching system }\end{array}$ \\
\hline $\begin{array}{l}\text { General } \\
\text { education } \\
\text { index }\end{array}$ & $\begin{array}{l}\text {-Percentage of learners being digitally profiled } \\
\text {-Percentage of students who were offered recommendations for improving } \\
\text { the quality of learning and the formation of individual trajectories using data } \\
\text { from the student's digital portfolio } \\
\text { - Share of teaching staff who have received the opportunity to use verified } \\
\text { digital educational content and digital educational services } \\
\text {-Percentage of learners with free access to verified digital educational } \\
\text { content and self-study services } \\
\text { - The proportion of electronic assignments for students checked using } \\
\text { automated verification technologies }\end{array}$ \\
\hline $\begin{array}{l}\text { Education and } \\
\text { Science Index }\end{array}$ & $\begin{array}{l}\text { - Share of employees of higher education institutions with digital } \\
\text { competencies } \\
\text {-Percentage of applicants using a full-fledged digital admission process for } \\
\text { OVE } \\
\text { - Share of OVOs integrated into the digital infrastructure of the Ministry of } \\
\text { Education and Science of the Russian Federation } \\
\text { - Share of additional professional educational programs implemented using e- } \\
\text { learning and distance learning technologies } \\
\text { - The share of scientific organizations integrated with the digital } \\
\text { infrastructure of the Ministry of Education and Science of the Russian } \\
\text { Federation } \\
\text { - Share of digitally provided shared services for researchers } \\
\text { - Share of R\&D in digital technology }\end{array}$ \\
\hline & e share of types of information in federal information systems, available \\
\hline
\end{tabular}




\begin{tabular}{|c|l|}
\hline $\begin{array}{c}\text { administration } \\
\text { index }\end{array}$ & $\begin{array}{l}\text { in electronic form, necessary for the provision of mass socially significant } \\
\text { services } \\
\text { - The share of electronic legally significant document flow in federal } \\
\text { executive bodies, off-budget funds and subordinate institutions } \\
\text { - Reducing the time of the actual provision of state and municipal services by } \\
\text { three times } \\
\text { - The share of state and municipal services provided without violating the } \\
\text { regulatory period } \\
\text { - The share of inspections within the framework of control and supervisory } \\
\text { activities carried out remotely, including using checklists in electronic form } \\
\text {-The share of applications for receiving state and municipal services in } \\
\text { electronic form among services that do not require face-to-face attendance } \\
\text {-The share of mass socially significant state and municipal services available } \\
\text { in electronic form }\end{array}$ \\
\hline
\end{tabular}

\section{Discussion and Conclusion}

When calculating the indicator of a territory's digital maturity, it is essential to determine each sub-indicator's contribution to the index's total mass. This moment's importance lies in understanding the criteria to mark territory as an outsider or a leader in digital maturity.

The critical point (the subject of a complex of further scientific research) of this methodology is selecting five key indices of digital transformation of territories. As mentioned earlier, the territory of the Russian Federation throughout its entire geographical extent has strong differentiation in terms of various indicators, a significant gap is observed in the redistribution of resources by the central parts of the territories of the Russian Federation and its periphery.

Therefore, we believe that sub-indicators' choice should be unique for individual territories since in certain territories, the culture of management (the structure of the economy) was formed under the influence of cultural, national, resource and other factors. For example, for a group of Russian Federation subjects, such as the Chelyabinsk and Sverdlovsk regions, it is possible to form single sub-indicators since the economy's structure is practically identical (historically formed metallurgical region). Nevertheless, the Tyumen region needs to be assessed by other sub-indicators since the economy's structure has a greater preponderance towards the extractive industry.

This methodology can be supplemented with a cluster approach to form various subindicators for territories grouped according to similar criteria. This approach will be used as an object of research in subsequent works.

\section{References}

1. A. Maltsev, V. Maltseva, An Overview of Key Expert Reports in 2019-2020 15(4), 189-195 (2020)

2. N. Kasavina, Digitalization as a Subject Matter of Interdisciplinary Studies 56(4), 251259 (2019)

3. I. Naumov, J. Dubrovskaya, E. Kozonogova, Spatial relationships Economy of Region 16(3), 896-910 (2020)

4. V. Tsirenshchikov, Sovremennaya Evropa 3, 104-113 (2019)

5. D. Pletnev, E. Nikolaeva, E. Silova, E3S Web of Conferences 13014, 210 (2020)

6. K. Chetty, L. Qigui, N. Gcora, J. Josie, L. Wenwei, C. Fang, Economics Discussion Papers 2017-69 (2017) 
7. J. Kirton, B. Warren, International Organisations Research Journal 13(2), 16-41 (2020)

8. T. Lanshina, V. Barinova, A. Kondratiev, M. Romantsov, Sustainable Development and Digitalization 15(4), 91-114 (2020)

9. S. El Massah, M. Mohieldinb, Ecological Economics 169, 106490 (2020) 